\title{
The days Argentina stood still. History, nation and imaginable futures in the public interpretations of the Argentine crisis at the beginning of the twenty-first century
}

Os dias em que Argentina parou. História, nação e futuro imaginável nas interpretações públicas da crise argentina no início do século XXI

Sergio E. Visacovsky

* Centro de Investigaciones Sociales, Instituto de Desarrollo Económico y Social / Consejo Nacional de Investigaciones Científicas y Técnicas Buenos Aires, Argentina sergio.visacovsky@ides.org.ar 


\begin{abstract}
This article is focused on public interpretations of the Argentine "crisis" at the beginning of the twenty-first century as necessary conditions for the constitution of the event. Such interpretations held that Argentina was dominated by a kind of evil force originated a long time ago, but whose effects persisted in the present. And, unless it was conjured once and for all, it would remain active and damaging in the future. Thus, the "crisis" was seen as an episode of the continuous failures. Based on opinion pieces or leading articles in newspapers and general interest and political magazines, academic articles and books, I want to show how the imagination of possible futures depended on the conceptions of temporalities implicit in the interpretations embedded in narratives and different valuations of events, figures and ideas. These gave historical specificity to the event and led to the emergence of new scenarios for political action.
\end{abstract}

Keywords: Argentine crisis; narrative; temporality; public interpretations.

\title{
Resumo
}

O propósito deste artigo é mostrar como as interpretações públicas da "crise" argentina no início do século XXI foram condições necessárias para a constituição do evento. Tais interpretações sustentavam que a Argentina era dominada por uma espécie de força maligna originada há muito tempo, mas cujos efeitos persistiram no presente. E, a menos que ela fosse conjurada de uma vez por todas, permaneceria ativa e prejudicial no futuro. Assim, a "crise" foi vista como um episódio do fracasso contínuo da nação. Com base em colunas de opinião ou editoriais em jornais e revistas de interesse geral e político, artigos acadêmicos e livros, quero mostrar como a imaginação de futuros possíveis dependia das concepções de temporalidades implícitas nas interpretações expressas em narrativas e diferentes avaliações de eventos, personagens e ideias. Estes deram especificidade histórica ao evento e levaram ao surgimento de novos cenários para a ação política.

Palavras-chave: crise argentina; narrativa; temporalidade; interpretações públicas. 


\section{Introduction $^{1}$}

At the beginning of 2003, Daniel Dessein, a prominent journalist, published the book Reinventar la Argentina. Reflexiones sobre la crisis. The book gathered several short articles, written by journalists, writers, historians, lawyers, political scientists, philosophers, art critics, sociologists and economists. Their goal was to think about the time they were living as a "crisis", which became de most prominent way of naming. In the foreword, Dessein argued that the central purpose of the volume was to answer fundamental questions in order to understand the present "crisis". These questions were: When did the country lose its "golden destiny"? What have been the causes of the "fall"? How responsible were the "politicians, economists, journalists, educators, intellectuals and citizens in general"? Were the Argentines "victims of a strange disease" or a kind of "fierce dialectic from which [they could not] escape"? The answer to these questions, then, was essential in order to know the destiny of Argentina, to glimpse a future (Dessein, 2003, p. 7-8).

Since the first weeks of December 2001 and even before, a vast amount of reflections like these circulated in the media and in publications such as academic articles and books; some of the latter became authentic best sellers (Fiorucci, 2004). They were written by economists and political scientists, but also other social scientists, historians, philosophers, artists, journalists and writers, all driven by the desire to elucidate the causes of the current situation and eager to propose possible solutions. Some of them were regular contributors

1 This article is the result of research carried out in the course of several projects financed by various institutions. My thanks especially to The Netherlands Organisation for Scientific Research (NOW, 2004-2006), the Universidad de Buenos Aires (2004-2007) and Fondo para la Investigación Científica y Tecnológica (FonCyT), Agencia Nacional de Promoción Científica y Tecnológica (ANPCyT), Ministerio de Ciencia, Tecnología e Innovación Productiva (2004-2007). Different previous versions have been presented and discussed in various scientific events; the first versions were written in collaboration with Patricia Vargas, who carried out a deep and fundamental documentary research. I am very grateful to Vargas, Claudio Lomnitz-Adler, Federico Neiburg, Antonius Robben, Ruben George Oliven, Mariano Plotkin, Rosana Guber, Ezequiel Adamovsky, Enrique Garguin, Diego Zenobi, Ricardo Fava (†), Alejandro Blanco, Moises Kopper, Sabina Frederic, David Parker, Daniel Ozarow, Susann Baez Ullberg, Jonathan Ablard, Sandra Gayol, Lorenzo Cañás Bottos, Gabriel Gatti, Julieta Quirós, Claudia Stern, Alejandro Castillejo-Cuéllar, Gabriela Mattina and Julieta Lenarduzzi for their criticism and suggestions. All translations of sources from Spanish to English are mine. 
in newspapers, magazines and radio and television programs; others were regarded as public and ethically upright figures. In those days, the Argentines were suffering a deep economic and financial collapse, massive unemployment and poverty, intense social protest and a lack of confidence in government institutions and in political leadership. The authors of the aforementioned writings agreed that although Argentina had experienced similar episodes in the past, the situation was the most terrible and profound in Argentine history.

According to the indicated texts, this "crisis" had immediate political and economic causes and its overcoming demanded urgent measures; however, from their perspective this explanation was insufficient: the "crisis" was not only economic and political, but "moral". Its ostensible manifestation was widespread corruption, especially concerning politicians. Evoking Mary Douglas (1966), Argentina was seen in these writings as a "dirty" and "impure" nation that needed urgent "purification". At the same time, these texts held that the causes that generated the current situation were not recent, but they came from the past and were active today. As essayist Juan José Sebreli (2004, p. 9) said:

The current collapse is not only the result of those responsible for the last mistakes; it is the inevitable consequence of years of accumulation of mistakes, crimes and ephemeral illusions. Its origins, the roots of evil, the serpent's egg, must be sought further and deeper, we must trace back the tortuous path that led us to the abyss.

Like Dessein, Sebreli and other interpreters of the presently called "crisis" shared the idea that Argentina was continually failing, making the same mistakes again and again, constantly moving from hope to frustration. In this sense, the current "crisis" was just one episode in a long history of failures; therefore, the roots of the evils of the present had to be sought through an inquiry of the past.

Usually, the notion of crisis is associated with discontinuity: something happens and puts an end to what existed so far. From the perspective of the medical conception in which this notion was originated, a crisis is a turning point because when it breaks out, it is impossible to know the outcome of a situation, i.e., if a patient will improve or worsen (Habermas, 1976; Holton, 1987; Koselleck, 1988). It is a temporary disruption in which the future does not appear as the predictable result of the continuity between past and present, so time is perceived as stagnant: something is no longer what it used to be, but it has 
not yet become what it is meant to be (Visacovsky, 2011b, 2017). The idea of crisis implies the inability to envision the future and it is, therefore, a time that can only be lived as uncertain (Koselleck, 1988); that is what Claudio Lomnitz-Adler (2003, p. 132) calls a present saturation, i.e., a collective aversion to socialize viable and desirable future images, close to the idea of frozen time (Visacovsky, 2017) and the classic liminality (Horvath; Thomassen; Wydra, 2015). Those undergoing the time of crisis cannot know how or when it will end, but they can still imagine possible outcomes; and in doing so, they forge possible solutions and scenarios for political action. How can the future be imagined under these circumstances? The most recent analyses on the financial crisis of 2007-2008 or the Greek debt crisis have shown the importance of the interpretations about the past for the recreation of the future (Bryant, 2016; Goddard, 2014; Knight, 2012a, 2012b, 2016, 2017; Knight; Stewart, 2016; Roitman, 2014). These interpretations embedded in narratives constitute a symbolic precondition for the organization of present experiences. A new future has to be designed and imposed on society, both by way of a consensus as well as by disputing other possible futures (Visacovsky, 2017). In parallel, the same perception of the crisis as a public and general issue must be imposed, as a critique (critique and crisis are related terms, see Koselleck, 1988; Roitman, 2014) of the current interpretation of a political project embodied in the state (Hay, 1996). ${ }^{2}$ The genesis of a perception of the future as uncertain is closely linked to the possibility of damaging trust in a hopeful future. In this way, any crisis can be seen as an attack on a certain political orientation, cutting off its idea of the future and, in short, replacing it with a new one.

Most studies about the so-called "Argentine crisis" were focused on its economic and political causes (Levey; Ozarow; Wylde, 2014). With the exception of few works (Armony, 2004; Armony; Armony, 2005; Goddard, 2006), less attention has been paid to the public interpretations of the situation. It is foolish to ignore the importance of the effects of economic policies on the lives of human populations. However, what I want to show here is the relevance of public interpretations of the situation as necessary conditions for the conformation of the "crisis" as an event (Hay, 1995, 1996; Kapferer, 2010; Sahlins, 1985;

2 As Colin Hay (1996) has shown in the case of the rise of Thatcherism in Great Britain in the mid1970s, the crisis must be narratively constructed as a diagnosis of the situation and a form of and a decisive intervention aimed at transforming the state. 
Turner, 1974). As I will show, during the time of "crisis" in Argentina the current situation was seen as an episode of the continuous failures of the country; therefore, far from being something unexpected, the current "crisis" was seen as a foreseeable event. As we saw in the cases of Dessein and Sebreli, the reasons for the continuous failures went back to the past. Such interpretations held that Argentina was dominated by a kind of evil force originated a long time ago, but whose effects persisted in the present. And, unless it was conjured once and for all, it would remain active and damaging in the future.

My study is based mainly on opinion pieces or leading articles in newspapers and general interest and political magazines; academic articles and books published mainly between the beginning of December 2001 and 2004, when the publication of these texts became increasingly discontinuous. I tackled these texts as narratives, focusing especially on: a) the characterization of the situation and its terminology; b) the reasons or causes that explain the situation as an object (crisis); c) the reasons or historical causes of the ills of Argentina; d) the temporal / chronological origins of the evils; e) the agents of evil (ideologies, political parties, political leaders); f) the connection of the present with the past or the way in which the evils of the present go back to the past (genealogies); g) the implicit time frame; h) the implicit or explicit resolution of the situation, the images of the future. Through this analysis, I identified three main narratives: "the Argentine decline", "the adolescent nation" and "the recurrent cycles". These are general plot schemes that differ in their implicit conceptions of temporality, under which lay distinctive versions of the national history. They are dissimilar in the way they assess events, figures and ideas (i.e. when the decline began and who was responsible for it). I want to show how the conceptions of temporality and the different valuation of events, characters and ideas were the conditions of possibility for the postulation of potential futures. On the one hand, the future could be imagined as the restoration of a promissory past, the passage from adolescent liminality to a state of adulthood, or the displacement of the present to the past and their constant vigilance. On the other, the moral evaluation allowed to postulate genealogical relations between events, characters and ideas of the present and the past (Valeri, 1990), differentiating "virtuous" from "malignant", morally acceptable from inacceptable relations (Visacovsky, 2002, 2011a). This gave historical specificity to the event and led to the emergence of new scenarios for political action. 


\section{“La crisis": its names and chronology}

The situation that erupted in December 2001 was the result of a long process that had begun much earlier. During the 1990s, economic policies were based on fiscal adjustment, foreign exchange liberalization, an open economy, banking deregulation, reduction of the role of the state; this caused the bankruptcy of private companies, the disappearance of state enterprises and the consequent growth of the informal sector and the increase of unemployment and poverty. The data showing that in September 200114 million out of the country's total population of 37 million (38 per cent) lived under the poverty line (Lozano, 2001), cannot be understood in the short term. From 1991 to 2000, in Gran Buenos Aires the unemployment rate rose from 6 to 17.9 per cent (Kessler; Di Virgilio, 2008). In May 2002, the national unemployment rate reached a record 21.5 per cent, meaning that the number of unemployed people rose to 2.8 million; meanwhile, precarious employment reached 56.9 per cent of the employed population and salaries were cut sharply. After the economic measures of January 2002, the population living below the poverty line increased significantly: 53 per cent of Argentines (19 million people). And nearly onefourth lived in misery (Instituto Nacional de Estadísticas y Censos, 2002). Certainly, the situation was extremely serious; in consequence, the new national authorities had to develop emergency measures to address these problems, particularly the urgencies of the neediest sectors (Heymann, 2006; Kosacoff, 2007).

On December 3, 2001 the government of the "Alianza para el Trabajo, la Justicia y la Educación" ("la Alianza") imposed severe restrictions on individual bank accounts (informally called corralito) under the pretext of preventing capital flight. Subsequently, on December 19 mass protests erupted, especially in the city of Buenos Aires: the famous cacerolazos, in which protesters, identified by the media as "middle class" (Visacovsky, 2009), expressed their anger by banging pots and pans and making a lot of noise. At the same time, on the outskirts of the city of Buenos Aires, impoverished sectors of the population ransacked supermarkets and other shops. Protests continued on December 20, ending in a bloody police repression at Plaza de Mayo and in other places, adding up to thirty-nine deaths across the country. This episode triggered the resignation of the entire executive branch, whose president was Fernando de la Rúa. After a brief period in which three presidents succeeded each 
other, on January 2, 2002 the Legislative Assembly elected Peronist Senator Eduardo Duhalde as president. The new administration decreed the end of the Convertibility Law, which had been in force since April 1st, $1991 .^{3}$ However, the critical situation continued during the following months, with high levels of public unrest (Camarasa, 2002; Jozami, 2003), even after Néstor Kirchner became president on May 25, 2003 (Giarraca, 2007). What this chain of events highlights is a political and economic order being disintegrated and leading to a new one. The "Argentine crisis" has often been presented with a supposedly accurate and indisputable chronology. However, as outlined below, identifying the "crisis" as a precise event is extremely difficult. Although economic and financial measures seem to be a reliable and objective instrument, the "crisis" was a much more ambiguous event from the point of view of social experiences.

During the aforementioned period, the word "crisis" was uttered by a number of experts as well as politicians, academics, artists and journalists, and propagated through mass media. This dominant term was accompanied or replaced by others such as "fall", "collapse", "crash" or "demolition". In many occasions, the term "crisis" was swapped for notions such as "earthquake" or "disaster". The situation was also conceived as "falling down a well"; therefore, some interpreters, as Abadi and Mileo (2002) and Altamirano (2002) agreed that "the Argentines had hit rock bottom". Different social actors frequently resorted to a medical analogy: as if the country was a patient in a serious and irreversible condition and whose death was clearly very close, "the crisis" was typified as "terminal" (see, e.g. Dessein, 2003, p. 7-8). Subsequently, other names were coined. Some leftist political groups defined the situation as Argentinazo especially pondering social protests (see Gordillo, 2012; Bonasso, 2001). In a similar sense, the state of affairs was defined as a "revolt", "rebellion", "revolution" or "explosion", expressions which were often accompanied by an adjective: "popular" (Dinerstein, 2003; Fradkin, 2005; Iñigo Carrera; Cotarelo, 2006; Pereyra, 2003). This conjuncture was also called "Tragic December", because the accent was put on repression. Nevertheless, here I want to focus

3 This law had been imposed by Carlos Menem's Peronist government; its purpose was to establish a fixed exchange rate between the national currency and the US dollar at the rate of 1 US dollar per 10,000 Australes (the legal currency in Argentina since 1985), that was later replaced by a new currency, the Peso Convertible, whose value was equal to 1 US Dollar from January 1, 1992. 
on the term "crisis", since it was the most customary label. As I will explain later, the situation was almost unanimously perceived as the end of an era or cycle.

However, there were many discrepancies regarding the identity and nature of the age that was ending. The prevailing interpretation stated that the "crisis" was the consequence of neoliberal policies of the 1990s and legitimacy problems at the beginning of the new century (Epstein; Pion-Berlin, 2006; Novaro, 2002; Ollier, 2003; Pírez, 2002; Rapoport, 2004; Teubal, 2004); as a consequence, these interpreters argued that what had concluded (or had to conclude) was the "neoliberal" era or cycle. Although this period was associated with Menem's government, some interpreters traced its origin back to the last dictatorship in 1976: thus, a genealogical relationship between Menemism and dictatorship was established. As I will show in the next section, many also agreed that a style of "politics" that had begun in 1983 with the return of democracy had ended; it had been characterized by corruption, unfulfilled electoral promises and political behind-the-scenes decision-making.

When did the situation begin to be labeled as a "crisis"? From December 3 (when the corralito was imposed) news stories from major newspapers agreed to set the scene as a "crisis". Nevertheless, the situation had already been categorized as such several months before. In December 2000, La Nación added a new section entitled "The lessons of the Argentine crisis. A series on the basic problems". Here opinion pieces written by prominent scientists, philosophers, writers and businessmen were published, which held that Argentina was frozen in time. To escape from this prison of the present, the country had to learn from the past, as well as other nations had done. Likewise, dreams and utopias were indispensable (Las enseñanzas..., 2000). These personalities stressed the need to build that new Argentina, the nation that did not exist.

After the events of late 2001, the onset of the "crisis" was increasingly confined to December, particularly 19 and 20. Most of the articles in the news and other writings considered that the "crisis" continued during the months following December 2001, after the commencement of Duhalde's presidency, even until after Kirchner took office as president on May 25, 2003. Kirchner himself said the "crisis" persisted throughout his presidency. From the beginning, he compared the ways to overcome the "crisis" with the passage of the souls of the dead from Hell to Paradise: they had to pass through the purification of Purgatory. Indeed, Kirchner said that his main goal was to get out of Hell in order to get to Purgatory, and 
in many occasions he stated: "we are still in Purgatory" (Bleta, 2006; Cufré, 2003; Kirchner le resta..., 2007; Kirchner prometió..., 2003; Kirchner volvió..., 2006; No anticipan..., 2006; Pérez de Eulate, 2007). A few months after the national presidential and legislative elections on October 28,2007 , this image enshrined the idea of an Argentina which was still living in a time of crisis; however, it was no longer paralyzed. That was the good news: a new time would soon ensue.

\section{A polluted nation}

The Alianza, the political coalition that the Unión Cívica Radical (UCR) and the Frente País Solidario (Frepaso) founded in 1997, triumphed in the elections of October 24, 1999, making de la Rúa president and Carlos “Chacho" Álvarez vice president. From the beginning, the Alianza sought to establish itself as an alternative force to Menemism. It characterized Menem's administration as the epitome of corruption (Astarita, 2014; Corral, 2014; Mauro, 2012); however, when the Alianza came to power its moral discourse was severely damaged due to a bribery scandal in the National Senate regarding the approval of a labor law reform. As a result, "Chacho" Álvarez resigned in early October 2000 (Juri, 2000).

Days before the legislative elections held on October 15, 2001 many citizens expressed their detachment and apathy towards the election. Mass media constantly disseminated the opinions of citizens who were disillusioned with the Alianza. Of course, not all the population had this attitude; it is likely that the media contributed to this situation. Anyway, this state of public opinion was reflected in the elections, which severely questioned the political leadership by a protest vote. ${ }^{4}$

In the midst of the "crisis", large segments of the population tried to explain the new circumstances through the behavior of politicians. They were considered

4 In these elections, 9.4 per cent of the voters did not choose any candidate (protest vote), reaching its highest level in 20 years (voting is mandatory in Argentina for all citizens between 18 and 70 years old); and 9 per cent of the votes were considered invalid according to the electoral laws (spoilt vote) (Blanquer; Cheresky, 2003; Escolar et al., 2002). After de la Rúa's resignation, the interpretation of disappointment and frustration at unfulfilled promises of the Alianza's government became an explanation of the debacle, especially considering the fury of the middle class (O’Donnell, 2001; Savoia, 2002). 
primarily responsible for having led the country into a desperate situation. During public protests people sang "que se vayan todos, que no quede ni uno solo" ("all of them must go, none of them should stay"), revealing the bitterness and hatred against political leaders. The governments of Menem, de la Rúa, Duhalde, and even Kirchner in his first years, as well as banks, judges and politicians in general were considered responsible for the debacle, blamed and characterized as corrupts, chorros (thieves) and mafiosi. Even some government officials, governors, legislators and judges were pursued and physically attacked in the streets. Politicians were seen as ambitious and greedy, villains (see, e.g. Kovadloff, 2002), astute beings that possessed the ability to seduce citizens with promises that would not be fulfilled later, when they became incumbents. In turn, politics was perceived as a dishonest way of life; hence, politicians were considered evil.

But this was not the only accusation. Indeed, others were also perceived as incompetent, allegedly because of their poor training for political leadership and their lack of conviction, courage and patriotism. In some cases, they were directly labelled as foolish. This was the case of de la Rúa, who had been deeply denigrated before his resignation. Mass media constructed an image of the president as stupid; he was constantly mocked. A few days before his resignation, some of his public appearances were heavily ridiculed and even some tried to attack him physically (Balmaceda, 2001). On several occasions, he was defined as "autistic" and "good-for-nothing". Philosopher and writer José Pablo Feinmann (2001) wrote: "[de la Rúa] was baptized Louis XXXII by the popular humor, because he was twice as boludo [dumb] as Luis XVI". He called him "Isabelito" (a diminutive of Isabel, the nickname of María Estela Martínez de Perón ("Isabelita"), third wife of Perón and president of Argentina after his death in 1974, who had been overthrown by the military coup of March 24, 1976) because of a similar inability and incompetence to govern. Such a comparison was strengthened with the pictures of the helicopters in which both left the Casa Rosada.

Corruption as a moral problem was considered to be the main cause of all evil. Argentina was "a society in a state of serious moral decomposition", as the journalist Sylvina Walger (2001) affirmed. Or as writer Mempo Giardinelli (2001) emphatically stated: "the problem of Argentina is not economic [...] it is political and above all moral [...]". Corruption was analogous to an illness that corroded morals and broke up social cohesion; Argentina could be seen as a country that was crumbling, routing to its dissolution. The image of a "republic 
ravaged by corruption and misgovernment" would even be invoked by Duhalde in his speech to the Legislature when he took over as president on January 2, 2002. Very often, corruption was described through body metaphors. These allowed interpreters to refer to the nation as a sick body, simultaneously with odors from its secretions or stool and widespread putrefaction. Thus, anyone could sense the "rotten smell", as writer and journalist Osvaldo Bayer (2002a) pointed out. Eschatological allusions were also frequent; corruption was like fecal matter falling on society; as Giardinelli (2002) said: "Those at the top defecate over those below". Those at the top were not just politicians; he also included managers, supervisors, entrepreneurs, all responsible for enslaving workers.

Very soon some interpreters postulated the existence of an alleged essence or nature of the Argentine people. Books like Argentinos, by journalist Jorge Lanata $(2002,2003)$ and Los mitos de la historia argentina, by history professor Felipe Pigna (2004) became best-sellers. Both posed a similar line of interpretation: on the one hand, there was an "official history" full of lies and concealments; on the other, a "true history" that had been "hidden" and needed to be revealed to the people. Despite their differences, both authors argued that Argentina had been a corrupt country since the Spanish conquerors set foot on this land in the sixteenth century (even though the Argentine nation did not exist yet); therefore, the current infected period was the continuation of a corrupt past, a past in which only some historical public figures considered unpolluted could be vindicated (Apaza, 2008; Carlos, 2005; De Amézola; Carnevale; González, 2009).

Nevertheless, as I argued, the decisive issue was to diagnose the evil that afflicted Argentina from the depths of history. As we will see below, these interpreters shared deep-seated beliefs about the causes of the nation's ills beyond ideological and political differences.

\section{The narratives of national history and the intelligibility of the "crisis"}

Apparently, there is nothing new under the sun regarding the traumatic process of Argentine decline and instability of the last twenty-five years, during which 
failures, tragedies and also fantasies of hope - later revoked - of a country presumably condemned to unlimited prosperity have proliferated. (Schutt, 2003, p. 475).

This was the way sociologist and political scientist Daniel Schutt described the "crisis" as a manifestation of the long decline of a country that supposedly should have achieved prosperity. Sebreli $(2004$, p. 13) also shared the idea that the "crisis" was the manifestation of a long decline, but at the same time argued that the reasons were mysterious:

The Argentine failure is a historical enigma difficult to decipher. What has happened to a nation that was one of the richest in the world at the beginning of the twentieth century, when fifty years later a gradual decline, almost imperceptible, began, to be followed by a vertiginous spiral that led to collapse at the beginning of the twenty-first century?

In these two fragments we can appreciate what I will call the narrative of decline: a drop that comes from afar and never stops; and a potential progress that never comes. But Sebreli adds a central element of this narrative: the question about the reasons for decline. In other words, how a country condemned to success (as President Duhalde asserted in March 2002) can fail irretrievably.

The emergence of this narrative can be dated at the beginning of the twentieth century, with the idea of "Argentine failure" (Kozel, 2007), the loss of faith in a promising future. This involved a challenge to the idea of progress, as it had been envisioned by Domingo Faustino Sarmiento, Juan Bautista Alberdi and Bartolomé Mitre in the second half of the nineteenth century. One of the best-known versions tells the story of a thriving, prosperous, wealthy country in the early twentieth century. This progressive time was the result of a civilizing process that had begun in 1853, when Juan Manuel de Rosas (Governor of Buenos Aires in 1829-1832 and the Province of Buenos Aires in 1835-1852; "a tyrant" according to this perspective) was defeated in the battle of Caseros. Since then, the country would have experienced a time of progress thanks to European immigration, export of grain and meat, the development of railways, roads, ports, mail and telegraph, and secular and free education. This same perspective holds that in 1900 the income per capita of Argentina, Germany 
and Canada was comparable; ${ }^{5}$ as a result, only seven countries in the world were wealthier than Argentina. In turn, this interpretation states that Argentina lost this privileged position during the course of the twentieth century due to the "demagogic policies" of Hipólito Yrigoyen (1916-1922 and 1928-1930) and Juan Domingo Perón (1946-1955). These governments and others later with similar characteristics led Argentina to veer from the path of modernity, since the foundational liberal values were replaced by nationalist ideals (later, "populism"). Lawyer and journalist José Ignacio García Hamilton - an advocate of this version of history, often defined as "liberal" - wondered: "Why did we abandon the principles of modernity and the path that had been so successful? Are we condemned to decline and failure"? (García Hamilton, 2003, p. 58). Coinciding with García Hamilton, doctor and journalist Nelson Castro (2003, p. 167) held that a "crisis of values" prevailed, in which a "culture of shortcut intended to supplant the compliance to the letter of the law", a consequence of the continuous coups d'état and political messianism. For his part, accountant and university professor Pedro José Frías (2003, p. 179) considered that the reason for the decline was the "leisure civilization", which had replaced the values of effort and work, typical of immigrants from Europe in the late nineteenth and early twentieth century. Leisure would have expanded due to Argentina's own wealth due to its status as the "world's barn". He argued that populisms (such as Yrigoyenism and Peronism) convinced the working and middle classes that effort was unnecessary, that welfare depended on the state.

The liberal version formed the basis from which other versions of decline were possible. The same temporal conception underlay a different assessment of events. From a Peronist perspective, the decline began with the fall of Perón's government in 1955. The presidential speeches of Adolfo Rodríguez Saá and Eduardo Duhalde before the Legislative Assemblies are a good example, since both highlighted that the first Peronism (1945-1955) was a time of "maximum well-being" for Argentines, a time that had to be recovered in order

5 On this basis, many interpreters have asked insistently "how and why other nations with similar characteristics managed to progress, while Argentina was plunged into frustration and hopelessness" (Muchnik, 2003, p. 17), as journalist Daniel Muchnik argued about Canada and Australia. In turn, a year before the crisis, journalist Jorge Oviedo (2000) alluded to the relationship between the three countries through a metaphor of kinship: "three sisters who were separated after birth". 
to return to the abandoned road. Rodríguez Saá proclaimed in December 23, 2001: “[...] I believe in the 'October 17' of the people that gave Perón [...] the opportunity to dignify the Argentines [...] I believe in the Peronist resistance [...]" (Diario..., 2001). For his part, Duhalde said in January 1, 2002:

I belong to a political movement that through former President Juan Domingo Perón and Eva Perón founded social justice in Argentina and raised the flags of economic independence and political sovereignty; flags that over time were assumed by all the political forces of popular origin. These flags have been lowered and today we have to ask ourselves and ask the Argentines if we really want to live in a sovereign and independent country. (Diario..., 2002).

For different reasons, some non-Peronist interpreters also pointed out that with the fall of Peronism a time of decline had begun. Historian Luis Alberto Romero (2003, p. 44) criticized the proscription of Peronism between 1955-1973 since this had impacted negatively on the democratic imaginary. Likewise, decline could go back to the first coup d'état in 1930 and, often, to the last military dictatorship. If decline was thought to be the result of the abandonment of a virtuous path, the resolution of the current "crisis" would be a sort of regression, a substitution of the decadent time by another virtuous one or the return to a righteous past. The result would be the restitution of a progressive time.

The "adolescent nation" was another important narrative, although less invoked (González, 2014). According to conservative lawyer and journalist Mariano Grondona, Argentina was an immature country. Reminiscent of the Kantian interpretation of the Enlightenment and based on analogies with life cycles (Herman, 1997; Vigh, 2008), he saw Argentina as a nation that had not reached adulthood, a country that was constantly changing moods: "The teenager expects too much from each change and therefore passes from illusion to frustration and from it to a new illusion. It is not necessary to renounce the utopia of a perfect tomorrow, but we should also reconcile with the modest reality [...]" (Grondona, 2001a). This story resembles the narrative of decline, since both imagine a progressive future time. In a way, decline can also be seen as a very long liminal time, as the future restoration of progressive time constitutes a promise that will be fulfilled without fail. The time of the "adolescent nation" also takes place in liminality (which admits oscillations, closer to 
a cyclical time), but adulthood is a state that has not yet emerged; it can only be glimpsed through the contemplation of those who have reached adulthood, such as the developed, "serious" and "normal" countries.

Another narrative saw crises as a constant in Argentine history, a manifestation of repetitive cycles, a foreseeable event produced by a permanent alternation between flourishing and decadent times. In this narrative, the present becomes unfailingly unstable because the worst is always to come, as journalist and writer Rodrigo Fresán (2001) affirmed: "The Argentine condition is linked to the catastrophe". The idea of crisis as an ever-emerging threat is deeply rooted among many social sectors. Like Grondona, much of the population wonders "how and when the next crisis will break out?" (Grondona, 2001b). Possibly it is a reasonable way of seeing things if we consider that during the last fifty or sixty years Argentines have experienced hyperinflations, devaluations, recessions, confiscations, capital flight, fiscal deficits, external debt, proscriptions, political violence, coups d'état, authoritarianism and state terrorism. It is not surprising that during the "crisis" many people recalled other similar episodes in the past: the "crisis" was part of a sequence of past "crises". Grondona rightly defined crises as "the almost routine expression of a periodically convulsed country"; he even postulated a frequency: "Argentina remains faithful to its custom, it explodes approximately every ten years" (Grondona, 2001b). In the same vein, political scientist Natalio Botana (2001) alleged: "Crises in Argentina constitute a relentless sequence. For many generations, normalcy is only an interval [...] crisis is not an exceptional moment in the country's march, but it imposes the historical seal of the longue durée". In other words, what was happening was not exceptional: it had already happened before. Perhaps the "crisis" was a severe blow; but that did not mean that this was neither the first nor the last stroke. Journalist Ignacio Escribano (2002) held that "the crisis was the mirror of a repeated history". ${ }^{6}$ Concerning the underlying temporality of the narrative of recurring cycles, nobody could ever be sure that the present that turned into past will not return: the declining present ejected into the past will constitute a permanent threat. The inauguration of a new time should also

6 The conception of time as "recurrent" is present in diverse interpretations of Argentine political and economic history in the twentieth century (Cavarozzi, 1983; Cerro, 1999; Damill; Frenkel, 1990; Damill, Frenkel; Juvenal, 2004; De Riz, 1984; Girón, 2009; Landi, 1979; Musacchio, 2009). 
be a prevention of the return of the fateful past. A permanent watch of the past will be indispensable; nobody will be able to relax because the substitution of a declining time for another prosperous one will be temporary: the past will always be a living force asleep and hidden in the present. ${ }^{7}$ As I will show in the following section, this narrative encompassed the rest, conditioning the imagination of possible futures.

\section{Glimpsing the future in uncertain times}

As I have pointed out, a consequence of crisis situations is, according to Lomnitz, the present saturation. Journalists like Susana Reinoso (2002) and Escribano (2002) reflected this perception by means of expressions such as "precarious state", the lack of "a firm floor under our feet", the impossibility to anticipate or overcome an unbearable present, or the "total absence of a project that helps us believe that tomorrow will exist". In the same way, philosopher Enrique Valiente Noailles (2002) lamented the uncertainty that "does not allow a minimal hope for the future". In his view, the main problem lay in an intolerable and precarious present "conditioned by our perception of the future" without hope. A few days before the outbreak of December 19, psychologist Eva Giberti (2001) affirmed that if "the national project is violated, it is meaningless to create personal projects [...] We need an experience of the future to develop projects". Similarly, writer and journalist Rodolfo Rabanal (2001) denunciated "the total absence of a useful project to believe in tomorrow".

The perception of time as frozen, stopped or in a state of suspension is distinctive of liminal instances; these are passages to a new state, which replaces the old one. In the major economic and political crises of contemporary capitalist societies, there are no pre-established ways (such as rituals) through which the passage or transition is processed, so the new state, the future, must be imagined (Visacovsky, 2017, p. 7-8). What is the raw material by which societies

7 Armony and Armony (2005) identified a narrative of the promise of a happy future, a country condemned to success (as Duhalde said during his presidency). However, this can be seen as a variant that postulates an imperative future, which could derive from any of the narratives presented here. 
elaborate the future when it is unimaginable? In the Argentine case, one way to create the future was through the purification of a present situation defined as "corrupt". Interpreters as Bayer (2002b) considered that some actors could carry out the role of purifiers, due to their unpolluted, incorruptible character. These actors were: Madres and Abuelas de Plaza de Mayo (seen as symbols of resistance to the last dictatorship since the democratic transition), the piqueteros, ${ }^{8}$ students, teachers and professors and eventually all humiliated and unemployed people. Bayer saw these actors as lighthouses to guide the people in the midst of the storm, or models to imitate, totally opposed to politicians, judges, trade unionists and business owners that had led the Argentines to disaster. Claims for a clean justice could also be seen in terms of sanitization. These involved the entire ideological and political spectrum and would very soon become a prominent part of the political agenda. Between 2002 and 2003, numerous demonstrations of citizens demanded the resignation of the members of the National Supreme Court of Justice, not only because they were held responsible for the confiscation of bank deposits, but also because they had colluded with political power. In fact, several members resigned and, already under his presidency, Néstor Kirchner promoted a total renovation of the Supreme Court (Kapiszewski, 2006; Ruibal, 2008). The reopening of trials for crimes committed by the last dictatorship can be considered part of this process of purification of justice, once the laws of Full Stop and Due Obedience (approved in 1986 and 1987 respectively and repealed by Congress in 1998) and the pardons decreed by President Menem between 1989-1990 were declared unconstitutional by the Congress (2003) and the Supreme Court (2005). Obviously, the initial demand of a sector of the citizenry to carry out a thorough purge of the political leadership was impracticable; see e.g. writer and journalist Antonio Caparrós (2002); and journalists Roberto Guareschi (2002) and Washington Uranga (2001). The reconstruction of the political system was conducted by more or less known politicians, many of which had already played various roles in government for several years.

8 The piquetero movement had begun in the protests of unemployed workers in Neuquén in 1996, caused by the dismissal of workers from the state company Yacimientos Petroliferos Fiscales, which was privatized during Menem's government; since then, their actions were characterized by the blockage of streets and routes (piquetes). 
If corruption was seen as a consequence of a "crisis of values", of the lack of honesty and decency, how could these qualities be recovered? "A look at the decades after 1853 shows us that progress is possible, if we return to positive values", according to García Hamilton (2003, p. 58). He was invoking the narrative of decline and a liberal vision of national history, according to which the future would consist in a return to the successful path abandoned many years ago, a restoration of lost time. These values could be embodied by certain historical figures with archetypal characteristics; or by the ancestors who came from Europe and progressed through hard work and sacrifice.

Others thought that Argentines should be more realistic in the future, because they are prone to living in a world of illusions. Terms such as "illusion" or "fiction" were used to define the support that broad sectors of society gave to convertibility after its repeal (see, e.g., economist Aldo Ferrer, 2001; journalist Marcelo Bonelli, 2001; engineer and economist Schvarzer, 2002, 2003; writer and journalist Tomás Eloy Martínez, 2005; journalist Martín Kanenguiser, 2011). A propensity to illusion that, as I showed in the previous section, was typical of an "adolescent nation" that had to reach maturity.

Now, we have seen that one of the peculiarities of the interpretations of Argentine history is that prosperous times are ephemeral. According to certain perspectives, the path of progress cannot be retrieved or, in other words, adulthood cannot be achieved due to the action of retrograde forces. Certainly, the restoration of progress or the passage to maturity are absorbed by a narrative in which cyclical temporality prevails. When history is interpreted in this way, the resolution of every crisis supposes the avoidance of a return of the ill-fated past, through either its eternal vigilance or, as Néstor Kirchner expounded in the Legislative Assembly on May 25, 2003, a definitive break in the cyclical logic. During and after the "crisis", the fear of an upcoming "crisis" has had performative effects in practices related to savings and investment, but it has also played a key role in the political contest. "If we lose, the country will return to 2001," Néstor Kirchner said before the 2009 legislative elections (Verón, 2009). A few years later, in a context of inflation and an increase in social conflict, sociologist Manuel Mora y Araujo warned about the possibility of a new "crisis" in Argentina (Dutra, 2013).

In turn, the idea of a cyclical temporality allowed for the imagination of the future as the end of a cycle and the beginning of a new one. This was sustained 
by interpreters that were critical of the 1990s, such as political scientist and sociologist Atilio Borón (2001) and Aldo Ferrer (2001); according to them, the fall of de la Rúa's government was the expiration of a neoliberal cycle, which had begun with the conclusion of the government of Isabel Perón and the policies of the minister of economy of the last military dictatorship, José Alfredo Martínez de Hoz. The cycle took the form of a genealogy, which established a relationship of descent between certain ideologies, governments, policies and characters of the present and their origins in the past. Thus, state terrorism and the economic policies of the last dictatorship was the genealogical origin of 1990s' neoliberalism.

The condemnation of neoliberalism affected government officials who planned and implemented the policies and politicians, economists, and journalists who defended them. Almost a year before the events of December, Muchnik (2001) did not hesitate to ask: "Did [the ministers of economy] Domingo Cavallo, Roque Fernández, José Luis Machinea, Ricardo López Murphy, [and neoliberal academic centers] CEMA, FIEL, Fundación Mediterránea and other factories and hotbeds of government officials have nothing to do with what is happening?". He remembered that they had sold public enterprises, tripled the external debt, destroyed labor laws, and expanded poverty. He argued: "They should be held accountable for what they did". ${ }^{9}$ The genealogical relationship that linked the last dictatorship with the 1990s was a way to identify the agents of pollution.

In contrast, a clean genealogy could face the task of future purification, such as imagining economic policies completely different from neoliberal ones. The so-called "Plan Fénix" is a good example of this. It was drawn up a few months before December 2001 by a group of economists at the University of Buenos Aires. The project, inspired by Keynes' ideas, postulated the central role of the state in order to boost economic growth, promote employment and consumption recovery and a more equitable distribution of income by developing import substitution industrialization and introducing dollar exchange controls. These economic ideas would be leading in the following years.

9 Voices identified as "neoliberal" were rarely heard on the public stage. A notable exception was Álvaro Alsogaray (2002), former economy minister in the government of Arturo Frondizi and de facto President José María Guido and advisor to President Menem. 
The various narratives are related hierarchically. Depending on their underlying temporalities, one narrative (or parts of it) can be transformed into another. The sequence progress-decline-progress very easily becomes a narrative of recurrent cycles. The narrative of an adolescent nation can be likened to the conception of decline, when the future of adulthood and progress is not achieved. In all cases, the narrative of recurrent cycles subsumes all the other narratives, transforming all progress, well-being and maturity into something transitory.

\section{Conclusions}

During the time coined as a "crisis" in Argentina a large number of public interpreters tried to explain its causes and possible solutions. Peculiarly, all these interpretations placed the "crisis" in national history. On the one hand, this was the appropriate frame to make the current time intelligible; on the other, the situation triggered a wide-ranging historical reflection on the misfortunes and destiny of the nation. Although this situation demanded immediate responses, the interpretations showed that a broad conviction existed: the evils that had led to the "crisis" were not a product of the present. These interpretations held that the overcoming of this corrupt time demanded an urgent political and moral purification. But, at the same time, the "crisis" was seen as crystallization of a repeated history of letdowns. Interpreters appealed to a series of narrative frames (Knight, 2012a, p. 356) that conceived the "crisis" as an expression of the "Argentine decline", as a new oscillation in the mood of an "adolescent nation", or, lastly, as part of "the recurrent cycles" in which prosperity and decay alternated. The unthinkable future after the "crisis" could be imagined through narratives. In all cases, the future presupposed the institution of a progressive time, but each narrative solved it in a different way. The narrative of decline demanded a return or restitution of a flourishing past; the narrative of the adolescent nation, called for the achievement of a state of maturity; and the narrative of recurrent cycles, required the definitive stoppage of the eternal recurrence. Although each narrative was autonomous, the narrative of the recurrent cycles has been dominant, transforming all the others. I do not claim that these narratives represent all interpretations of the time 
of "crisis". I have focused on public interpretations, but others could be thought of and spread by popular sectors, for example. However, many of these public interpretations had consequences in the practices and everyday life of the population, since they gave rise to specific policies.

I would like to highlight three reasons why it is important to study public interpretations of the "crisis". First, the "crisis" revealed (Knight, 2012a, p. 369) deep-rooted ways of imagining the nation and a sense of historicity; a present embedded in national history, with its specific interpretations and, consequently, potential solutions or projects. The past (or its narratives) constituted models through which the nation could be thought (Sahlins, 1985). Second, the interpretative disputes about the time of "crisis" forged specific meanings of the event. It is clear that widespread corruption and neoliberal economic policies were preponderant aspects that had led to disaster (without euphemisms). This was expressed by public interpretations of the "crisis". However, many of these interpretations did something else: they postulated the need for a specific type of political intervention (Hay, 1996). For that reason the exit of the "crisis" implied a different path from the neoliberal one. In short, the nomination of a time as "crisis" is inseparable from its interpretations, from the imaginable futures and from certain and new courses of political action (Bryant, 2016, p. 26). Third, the exit from the "crisis" allows us to understand the political and economic process that follows. This seems like a truism, but I mean something a little less obvious. I suggest that the interpretative disputes that constituted the "crisis" as an event produced a political setting in which certain actions were possible and admissible, to the detriment of others. The strong public condemnation of the policies of the 1990s and their leaders enabled forms of intervention that were presented as opposed. Taking into account Duhalde's government and the first years of Kirchner's, we see that the economic policy was more state-oriented; different programs to address poverty and unemployment were implemented; or the trials of those responsible for state terrorism were reopened. I conjecture that, perhaps, the same can be applied to other aspects of "Kirchnerism" (a local term that is often used uncritically to refer to different times and policies), such as its invocations to certain pasts seen as exemplary and the construction of genealogies, the relationship with a "recovery of the political" or the return of the "participation of youth in politics". 
Finally, this article aims to be a contribution to the novel field of studies on crisis situations, especially in anthropology. These can help understand aspects not covered by macroeconomic or political analyses. From a nonnormative perspective, based on empirical research and an analytical arsenal sensitive to the native's perspectives, these investigations show how each crisis is specific, because its interpretation is only possible within particular frames and historicities. Crises (in an economic sense) may obey the universal logic of capitalism; but the Argentine "crisis" is a multidimensional event only intelligible within a specific sense of historicity. Like the studies on Spain and (mainly) Greece, the Argentine case highlights the relevance of cultural dimensions to understand the collective responses that each country has assumed as a national project.

\section{References}

ABADI, J.; MILEO, D. Tocar fondo: la clase media argentina en crisis. Buenos Aires: Sudamericana, 2002.

ALSOGARAY, A. El punto de no retorno. Ámbito Financiero, Buenos Aires, p. 8, 6 feb. 2002.

ALTAMIRANO, C. ¿Quo vadis, Argentina?. Estudos Avançados, São Paulo, v. 16, n. 44, p. 69-82, 2002.

APAZA, H. Divulgadores de la historia, público y sentido común. KAF, Santa Fe, v. 1, n. 1, p. 44-52, 2008.

ARMONY, C.; ARMONY, V. Indictments, myths, and citizen mobilisation in Argentina: a discourse analysis. Latin American Politics and Society, Miami, v. 47, n. 4, p. 27-54, 2005.

ARMONY, V. L'énigme argentine: images d'une société en crise. Montréal: Athéna éditions: Chaire de recherche du Canada en mondialisation citoyenneté et démocratie, 2004.

ASTARITA, M. Los usos políticos de la corrupción en la Argentina en los años noventa: una perspectiva histórica. Revista Estado y Políticas Públicas, Buenos Aires, v. 2, n. 3, p. 171-190, 2014.

BALMACEDA, O. De la Rúa exigió respeto por la investidura tras ser abucheado. La Nación, Buenos Aires, 18 mayo 2001. Política, p. 8. 
BAYER, O. De Monseñor a Bakunin. Página 12, Buenos Aires, 20 dic. 2002a. Especiales, p. 24.

BAYER, O. La gran fachada argentina. Página 12, Buenos Aires, 6 enero 2002b. El País, p. 23.

BLANQUER, J.-M.; CHERESKY I. De la ilusión reformista al descontento ciudadano: las elecciones en Argentina, 1999-2001. Rosario: Homo Sapiens, 2003.

BLETA, A. Kirchner volvió a mostrarse con Cristina y habló del fin del mandato. Clarín, Buenos Aires, 11 nov. 2006. Noticias, p. 4.

BONASSO, M. El reencuentro. Tres Puntos, Buenos Aires, 23 dic. 2001. Sección, p. 22-23.

BONELLI, M. Un final anunciado, para una década de convertibilidad. Clarín, Buenos Aires, 21 dic. 2001. Política, p. 11.

BORÓN, A. Réquiem para el neoliberalismo. Página 12, Buenos Aires, p. 25, 23 dic. 2001.

BOTANA, N. Sobrevivir en la crisis. La Nación, Buenos Aires, 20 dic. 2001. Notas, p. 25.

BRYANT, R. On critical times: return, repetition, and the uncanny present. History and Anthropology, London, v. 27, n. 1, p. 19-31, 2016.

CAMARASA, J. Días de furia: historia oculta de la Argentina desde la caída de de la Rúa hasta la asunción de Duhalde. Buenos Aires: Sudamericana, 2002.

CAPARRÓS, M. Qué país: informe urgente sobre la Argentina que viene. Buenos Aires: Planeta, 2002.

CARLOS, M. Los usos de la Historia y el fenómeno de la 'nueva divulgación' en el campo de la Historia Argentina. Clío y Asociados, La Plata, n. 9/10, p. 131-148, 2005.

CASTRO, N. La crisis de valores. In: DESSEIN, D. (Comp.). Reinventar la Argentina: reflexiones sobre la crisis. Buenos Aires: Sudamericana: La Gaceta de Tucumán, 2003. p. 166-169.

CAVAROZZI, M. Autoritarismo y democracia (1955-1983). Buenos Aires: Centro Editor de América Latina, 1983.

CERRO, A. M. La conducta cíclica de la economía argentina y el comportamiento del dinero en el ciclo económico. Económica, La Plata, v. 45, n. 4, p. 7-60, 1999.

CORRAL, D. En torno a la política como 'problema moral'. El clivaje corrupción-anticorrupción como principio de diferenciación política en la centroizquierda de los noventa. Trabajo y Sociedad, Santiago del Estero, n. 22, p. 447-459, 2014. 
CUFRÉ, D. Kirchner quiere salir del infierno mientras los empresarios piden palos. Página 12, Buenos Aires, 12 dic. 2003. Economía, p. 2.

DAMILL, M.; FRENKEL, R. Hiperinflación en Argentina: 1989-1990. Buenos Aires: CEDES, 1990.

DAMILL, M.; FRENKEL, R.; JUVENAL, L. Las cuentas públicas y la crisis de la convertibilidad en Argentina. Journal of Iberian and Latin American Research, Sydney, v. 10, n. 2, p. 61-94, 2004.

DE AMÉZOLA, G.; CARNEVALE, S.; GONZÁLEZ, M. P. Los futuros profesores y las lecturas de historia en las aulas de Argentina. Antíteses, Londrina, v. 2, n. 3, p. 93-113, 2009.

DE RIZ, L. Argentina: ni democracia estable ni régimen militar (conjeturas sobre las perspectivas para la democracia). In: OSZLAK, O. et al. 'Proceso', crisis y transición democrática/2. Buenos Aires: Centro Editor de América Latina, 1984. p. 7-28.

DESSEIN, D. (Comp.). Reinventar la Argentina: reflexiones sobre la crisis. Buenos Aires: Sudamericana: La Gaceta de Tucumán, 2003.

DIARIO de sesiones de la Asamblea legislativa. Versión taquigráfica. Buenos Aires, 22/23 dic. 2001. Available at: <http://constitucionweb.blogspot.com.ar/2010/03/ asamblea-legislativa-del-23122001.html>. Accessed: 3 June 2018.

DIARIO de sesiones de la Asamblea legislativa. Versión taquigráfica. Buenos Aires, 1 enero 2002.

DINERSTEIN, A. ¡Que se vayan todos! Popular insurrection and the asambleas barriales in Argentina. Bulletin of Latin American Research, Liverpool, v. 22, n. 2, p. 187-200, 2003.

DOUGLAS, M. Purity and danger: an analysis of concepts of pollution and taboo. London: Routledge, 1966.

DUTRA, D. Hay una posibilidad de crisis en Argentina como en 2001. El Observador, Montevideo, 18 dic. 2013. Mundo, p. 12.

EPSTEIN, E.; PION-BERLIN, D. (Ed.). Broken promises?: the Argentine crisis and Argentine democracy. Lanham: Lexington Books, 2006.

ESCOLAR, M. et al. Últimas imágenes antes del naufragio: las elecciones del 2001 en Argentina. Desarrollo Económico, Buenos Aires, v. 42, n. 165, p. 25-44, 2002.

ESCRIBANO, I. Espejos de una historia que se repite. La Nación, Buenos Aires, 8 enero 2002. Notas, p. 21.

FEINMANN, J. P. Isabelito. Página 12, Buenos Aires, p. 11, 21 Dec. 2001. 
FERRER, A. Los mitos neoliberales versus la capacidad económica estatal. Clarín, Buenos Aires, 11 dic. 2001. Tribuna Abierta, p. 23.

FIORUCCI, F. Fascinated by failure: the 'bestseller' explanations of the crisis. In: FIORUCCI, F.; KLEIN, M. The Argentine crisis at the turn of the millennium. Amsterdam: CEDLA, 2004. p. 150-172.

FRADKIN, R. Cosecharás tu siembra. Notas sobre la rebelión popular argentina de diciembre 2001. Nuevo Mundo Mundos Nuevos, Paris, 9 févr. 2005.

FRESÁN, R. Argentino de lejos. Página 12, Buenos Aires, 31 dic. 2001. Informe Especial, p. 16.

FRÍAS, P. J. Reinvertarnos en la penuria. In: DESSEIN, D. (Comp.). Reinventar la Argentina: reflexiones sobre la crisis. Buenos Aires: Sudamericana: La Gaceta de Tucumán, 2003. p. 178-180.

GARCÍA HAMILTON, J. I. Esplendor y ocaso de la República Argentina. In: DESSEIN, D. (Comp.). Reinventar la Argentina: reflexiones sobre la crisis. Buenos Aires: Sudamericana: La Gaceta de Tucumán, 2003. p. 56-58.

GIARDINELLI, M. De contubernios y monipolios. Página 12, Buenos Aires, p. 40, 6 dic. 2001.

GIARDINELLI, M. La ley del gallinero y una teoría de las cacerolas. Página 12, Buenos Aires, p. 28, 7 enero 2002.

GIARRACA, N. Tiempos de rebelión: que se vayan todos: calles y plazas en la Argentina 2001-2002. Buenos Aires: Antropofagia, 2007.

GIBERTI, E. El futuro. Página 12, Buenos Aires, p. 36, 14 dic. 2001.

GIRÓN, A. Argentina: su recurrente inestabilidad financiera. Buenos Aires: CLACSO; México: Universidad Nacional Autónoma de México/IIES, 2009.

GODDARD, V. This is history: nation and experience in times of crisis - Argentina 2001. History and Anthropology, London, v. 17, n. 3, p. 267-286, 2006.

GODDARD, V. Fronteras, fragmentos y el proyecto antropológico: género y generaciones en el capitalismo contemporáneo. In: TOMÀS, A. A. et al. Periferias, fronteras y diálogos: una lectura antropológica de los retos de la sociedad actual. Tarragona: Publicacions Universitat Rovira i Virgili, 2014. p. 87-107.

GONZÁLEZ, F. Crónicas de un país adolescente: siete décadas de proyectos delirantes. Buenos Aires: Ediciones B, 2014.

GORDILLO, M. Piquetes y cacerolas: el “argentinazo” del 2001. Buenos Aires: Sudamericana, 2012. 
GRONDONA, M. Un país entre la adolescencia y la madurez. La Nación, Buenos Aires, 23 dic. 2001a. Notas, p. 25.

GRONDONA, M. Los argentinos ¿ingobernables o desgobernados?. La Nación, Buenos Aires, 30 dic. 2001b. Notas, p. 21.

GUARESCHI, R. Si no es ahora, ¿cuándo?. Clarín, Buenos Aires, 2 enero 2002. Política, p. 5 .

HABERMAS, J. Legitimation crisis. London: Heinemann, 1976.

HAY, C. Rethinking crisis: narratives of the new right and constructions of crisis. Rethinking Marxism: A Journal of Economics, Culture \& Society, Amherst, v. 8, n. 2, p. 60-76, 1995.

HAY, C. Narrating crisis: the discursive construction of the Winter of Discontent. Sociology, Durham, v. 30, n. 2, p. 253-277, 1996.

HERMAN, A. The idea of decline in Western History. New York: Simon and Schuster, 1997.

HEYMANN, D. Buscando la tendencia: crisis macroeconómica y recuperación en Argentina. Buenos Aires: CEPAL, 2006. (Serie Estudios y Perspectivas).

HOLTON, R. J. The idea of crisis in modern society. The British Journal of Sociology, v. 38, n. 4, p. 502-520, 1987.

HORVATH, A.; THOMASSEN, B.; WYDRA, H. (Ed.). Breaking boundaries: varieties of liminality. Oxford: Berghahn, 2015.

INSTITUTO NACIONAL DE ESTADÍSTICAS Y CENSOS. Encuesta Permanente de Hogares (EPH). Buenos Aires, mayo 2002.

IÑIGO CARRERA, N.; COTARELO, M. C. Génesis y desarrollo de la insurrección espontánea de diciembre de 2001 en Argentina. In: CAETANO, G. Sujetos sociales y nuevas formas de protesta en la historia reciente de América Latina. Buenos Aires: CLACSO, 2006. p. 49-92.

JOZAMI, A. Argentina, la destrucción de una nación. Buenos Aires: Mondadori, 2003.

JURI, D. Chacho renunció con críticas y De la Rúa dice que no hay crisis. Clarín, Buenos Aires, 7 oct. 2000. Política, p. 4.

KANENGUISER, M. Fin de la ilusión: Argentina 2001-2011: crisis, reconstrucción y declive. Buenos Aires: Edhasa, 2011.

KAPFERER, B. In the event: toward an anthropology of generic moments. Social Analysis, v. 54, n. 3, p. 1-27, 2010. 
KAPISZEWSKI, D. La Corte Suprema y la política constitucional en la Argentina post-Menem. Revista Jurídica de la Universidad de Palermo, Buenos Aires, n. 1, p. 5-46, 2006.

KESSLER, G.; DI VIRGILIO, M. M. La nueva pobreza urbana: dinámica global, regional y argentina en las últimas dos décadas. Revista de la CEPAL, Santiago de Chile, n. 95, p. 31-50, 2008.

KIRCHNER le resta dramatismo a la discusión salarial. La Nación, Buenos Aires, 13 abr. 2007. Política, p. 7.

KIRCHNER prometió transparencia. La Nación, Buenos Aires, 12 dic. 2003. Economía y Negocios, 2da. Sección, p. 4.

KIRCHNER volvió a pedir que no se pierda el tiempo en campaña y resaltó logros económicos. Clarín, Buenos Aires, 21 dic. 2006. Política, p. 7.

KNIGHT, D. M. Cultural proximity: crisis, time and social memory in central Greece. History and Anthropology, London, v. 23, n. 3, p. 349-374, 2012 a.

KNIGHT, D. M. Turn of the screw: narratives of history and economy in the Greek crisis. Journal of Mediterranean studies, Malta, v. 21, n. 1, p. 53-76, 2012b.

KNIGHT, D. M. Temporal vertigo and time vortices on Greece's Central Plain. The Cambridge Journal of Anthropology, Cambridge, v. 34, n. 1, p. 32-44, 2016.

KNIGHT, D. M. Fossilized futures: topologies and topographies of crisis experience in Central Greece. Social Analysis, New York, v. 61, n. 1, p. 26-40, 2017.

KNIGHT, D. M.; STEWART, C. Ethnographies of austerity: temporality, crisis and affect in Southern Europe. History and Anthropology, London, v. 27, n. 1, p. 1-18, 2016.

KOSACOFF, B. (Ed.). Crisis, recuperación y nuevos dilemas: la economía argentina 2002-2007. Santiago de Chile: Naciones Unidas: CEPAL, 2007.

KOSELLECK, R. Critique and crisis: enlightenment and the pathogenesis of modern society. Learnington Spa: Berg, 1988.

KOVADLOFF, S. La tensa espera. La Nación, Buenos Aires, 9 enero 2002. Notas, p. 17.

KOZEL, A. En torno a la desilusión argentina. Varia Historia, Belo Horizonte, v. 23, n. 38, p. 368-385, 2007.

LANATA, J. Argentinos: desde Pedro de Mendoza hasta la Argentina del Centenario. Buenos Aires: Ediciones B: Grupo Zeta, 2002.

LANATA, J. Argentinos: siglo XX: desde Yrigoyen hasta la caída de de la Rúa. Buenos Aires: Ediciones B: Grupo Zeta, 2003. 
LANDI, O. Argentina 1973-76: la génesis de una nueva crisis política. Revista Mexicana de Sociología, México D.F., v. 41, n. 1, p. 89-127, 1979.

LAS ENSEÑANZAS de la crisis argentina. Una serie sobre los problemas de fondo. $\mathrm{La}$ Nación, Buenos Aires, 31 dic. 2000. Cultura, p. 15.

LEVEY, C.; OZAROW D.; WYLDE C. Argentina since the 2001 crisis: recovering the past, reclaiming the future. New York: Palgrave Macmillan, 2014.

LOMNITZ-ADLER, C. Times of crisis: historicity, sacrifice and the spectacle of debacle in Mexico City. Public Culture, Durham, v. 15, n. 1, p. 127-147, 2003.

LOZANO, C. Contexto económico y político en la protesta social de la Argentina contemporánea. Observatorio Social de América Latina, Buenos Aires, n. 5, p. 5-10, 2001.

MARTÍNEZ, T. E. The truth in fiction. New Perspectives Quarterly, Santa Barbara, v. 22, n. 3, p. 25-28, 2005.

MAURO, S. La tematización de la corrupción como clivaje de la política argentina en los noventa. Estudios Sociales, Santa Fe, v. 20, n. 40, p. 68-95, 2012.

MUCHNIK, D. La economía, en la cuenta regresiva. Clarín, Buenos Aires, 16 enero 2001. Noticias, p. 10.

MUCHNIK, D. Tres países, tres destinos: Argentina frente a Australia y Canadá. Buenos Aires: Norma, 2003.

MUSACCHIO, A. Las oscilaciones cíclicas de la economía argentina en las dos últimas décadas. Problemas del Desarrollo, México D.F., v. 40, n. 159, p. 143-168, 2009.

NO ANTICIPAN las elecciones. La Nación, Buenos Aires, 23 jun. 2006. Política, p. 8.

NOVARO, M. (Comp.). El derrumbe político en el ocaso de la convertibilidad. Buenos Aires: Norma, 2002.

O’DONNELL, S. El cacerolazo, la nueva forma de fiscalizar. La Nación, Buenos Aires, 23 dic. 2001. Política, p. 13.

OLLIER, M. M. Argentina: up a blind alley once again. Bulletin of Latin American Research, Liverpool, v. 22, n. 2, p. 170-186, 2003.

OVIEDO, J. La Argentina, Canadá y Australia parecen tres hermanas separadas al nacer. La Nación, Buenos Aires, 27 agosto 2000. Economía y Negocios, 2da. Sección, p. 1-2.

PEREYRA, D. Argentina rebelde: crónica y enseñanzas de la revuelta social. Madrid: Ediciones de Intervención Cultural: El Viejo Topo, 2003. 
PÉREZ DE EULATE, M. Kirchner prometió continuidad económica a los empresarios. La Nación, Buenos Aires, 2 agosto 2007. Economía y Negocios, 2da. Sección, p. 1-2.

PIGNA, F. Los mitos de la historia argentina. Buenos Aires: Norma, 2004.

PÍREZ, P. ¿Qué pasó en la Argentina? Algunas piezas de un rompecabezas para intentar entender. Estudios Sociológicos, México D.F., v. 20, n. 2, p. 455-467, 2002.

RABANAL, R. La Argentina desenmascarada. La Nación, Buenos Aires, 19 dic. 2001. Notas, p. 21.

RAPOPORT, M. (Ed.). Crónicas de la Argentina sobreviviente: el presente en el espejo de la historia. Buenos Aires: Norma, 2004.

REINOSO, S. Hubo críticas de los intelectuales. La designación de Duhalde es vista con desconfianza y un atisbo de esperanza. La Nación, Buenos Aires, 3 enero 2002. Política, p. 8.

ROITMAN, J. Anti-crisis. Durham: Duke University Press, 2014.

ROMERO, L. A. La crisis argentina: una mirada al siglo XX. Buenos Aires: Siglo Veintiuno, 2003.

RUIBAL, A. M. La sociedad civil en el proceso de reformas a la Corte Suprema Argentina. Revista Mexicana de Sociología, México D.F., v. 70, n. 4, p. 725-757, 2008.

SAHLINS, M. Islands of History. Chicago: The University of Chicago Press, 1985.

SAVOIA, C. Una democracia acorralada. Clarín, Buenos Aires, 1 enero 2002. Suplemento Especial, p. 3.

SCHUTT, D. Argentina 2001-2002: agonía, estallido y naufragio. Foro Internacional, México D.F., v. 43, n. 2, p. 475-493, 2003.

SCHVARZER, J. El fracaso histórico de la convertibilidad. Iberoamericana, Berlín, v. 2, n. 6, p. 190-194, 2002.

SCHVARZER, J. La crisis en Argentina: el fracaso histórico de un sistema perverso. Revista Europea de Estudios Latinoamericanos y del Caribe, Amsterdam, n. 74, p. 85-92, 2003.

SEBRELI, J. J. Crítica de las ideas políticas argentinas: los orígenes de la crisis. Buenos Aires: Sudamericana, 2004.

TEUBAL, M. Rise and collapse of Neoliberalism in Argentina. The role of economic groups. Journal of Developing Societies, New Delhi, v. 20, n. 3/4, p. 173-188, 2004.

TURNER, V. W. Dramas, fields and metaphors: symbolic action in human society. Ithaca: Cornell University Press, 1974. 
URANGA, W. El deporte nacional. Página 12, Buenos Aires, p. 28, 10 dic. 2001.

VALERI, V. Constitutive history: genealogy and narrative in the legitimation of Hawaiian kingship. In: OHNUKI-TIERNEY, E. Culture through time: anthropological approaches. Stanford: Stanford University Press, 1990. p. 154-192.

VALIENTE NOAILLES, E. El principio de la esperanza. La Nación, Buenos Aires, 3 enero 2002. Notas, p. 17.

VERÓN, M. 'Si perdemos, el país volverá al 2001', dijo Kirchner. La Nación, Buenos Aires, 28 abr. 2009. Política, p. 1, 5.

VIGH, H. Crisis and chronicity: anthropological perspectives on continuous conflict and decline. Ethnos, Stockholm, v. 73, n. 1, p. 5-24, 2008.

VISACOVSKY, S. E. El Lanús: memoria y política en la construcción de una tradición psiquiátrica y psicoanalítica argentina. Buenos Aires: Alianza, 2002.

VISACOVSKY, S. E. Imágenes de la 'clase media' en la prensa escrita argentina durante la llamada 'crisis del 2001-2002'. In: VISACOVSKY, S. E.; GARGUIN, E. Moralidades, economías e identidades de clase media: estudios históricos y etnográficos. Buenos Aires: Antropofagia, 2009. p. 247-278.

VISACOVSKY, S. E. Imputaciones de colaboracionismo, moralidad política y los orígenes y difusión del lacanismo en la Argentina. Etnografías Contemporáneas, v. 5, n. 5, p. 75-107, 2011a.

VISACOVSKY, S. E. Introducción. In: VISACOVSKY, S. E. Estados críticos: la experiencia social de la calamidad. La Plata: Al Margen, 2011b. p. 15-63.

VISACOVSKY, S. E. When time freezes: socio-anthropological research on social crises. Iberoamericana: Nordic Journal of Latin American and Caribbean Studies, Stockholm, v. 46, n. 1, p. 6-16, 2017.

WALGER, S. Un paquete de escepticismo. La Nación, Buenos Aires, 7 dic. 2001. Notas, p. 25.

Recebido: 30/09/2017 Aceito: 20/06/2018 | Received: 9/30/2017 Accepted: 6/20/2018 